\title{
- ANALIZA UKOŃCZENIA PRZEZ PIELĘGNIARKI I POŁOŻNE KURSÓW SPECJALISTYCZNYCH NA TERENIE DZIALANIA KOSZALIŃSKIEJ RADY PIELĘGNIAREK I POŁOŻNYCH
}

\section{ANALYSIS OF SPECIALIZATION COURSES COMPLETION BY NURSES AND MIDWIVES IN THE KOSZALIN COUNCIL OF NURSES AND MIDWIVES OPERATION AREA}

\author{
Justyna Laska ${ }^{1}$, Dorota Ćwiek ${ }^{2}$, Dorota Fryc ${ }^{2}$, Małgorzata Zimny², Katarzyna Szymoniak ${ }^{2}$ \\ ${ }^{1}$ Koszalińska Rada Pielęgniarek i Położnych \\ ${ }^{2}$ Samodzielna Pracownia Umiejętności Położniczych \\ Pomorski Uniwersytet Medyczny w Szczecinie
}

DOI: https://doi.org/10.20883/pielpol.2017.10

\section{STRESZCZENIE}

Wstęp. Nowoczesne pielęgniarka i położna stale aktualizują wiedzę i doskonalą umiejętności. Konieczność ustawicznego doskonalenia zawodowego wynika z obowiązku nałożonego przez Ustawę (...) o zawodzie pielęgniarek i położnych, Kodeks etyki zawodowej (...), ale także z potrzeby nadążania za stale zmieniającymi się naukami medycznymi.

Cel. Cele pracy to analiza ukończenia przez pielęgniarki i położne regionu koszalińskiego kursów specjalistycznych przeprowadzonych w ramach szkolenia podyplomowego oraz wykazanie, czy wykonywany zawód pielęgniarki lub położnej, staż pracy, miejsce zamieszkania, wykształcenie i miejsce pracy miały wpływ na liczbę ukończonych kursów specjalistycznych.

Materiał i metody. Grupę badaną stanowiły 153 osoby z personelu pielęgniarskiego i 17 położnych zarejestrowanych w Okręgowej Izbie Pielęgniarek i Położnych w Koszalinie, które uczestniczyły w kształceniu podyplomowym. W celu przeprowadzenia badań zastosowano metodę sondażu diagnostycznego, wykorzystując technikę ankietową. Jako narzędzie badawcze posłużył samodzielnie skonstruowany kwestionariusz ankiety zawierającej 27 pytań. Anonimowe badania poddano analizie opisowej, graficznej oraz statystycznej.

Wnioski. W wyniku przeprowadzonych badań wyciągnięto następujące wnioski: 1. Niemal wszyscy badani posiadali ukończone kursy specjalistyczne. Świadczy to o wysokiej świadomości podnoszenia kwalifikacji niezbędnych do wykonywania określonych czynności zawodowych. 2. Najczęściej respondenci kończyli kurs specjalistyczny „Wykonanie i interpretacja zapisu elektrokardiograficznego”, następnie „Resuscytacja krążeniowo-oddechowa” i „Szczepienia ochronne”. 3. Miejsce pracy statystycznie istotnie wpłynęło na liczbę ukończonych kursów specjalistycznych przez pielęgniarki i położne. Pozostałe analizowane zmiennie: staż pracy, wykształcenie, struktura zawodu i miejsce zamieszkania nie miały takiego wpływu.

SŁOWA KLUCZOWE: kształcenie podyplomowe, pielegniarki, położne.

\section{Wstęp}

Nowoczesne pielęgniarka i położna stale aktualizują wiedzę i doskonalą umiejętności. Konieczność ustawicznego doskonalenia zawodowego wynika nie tylko z sa-

\begin{abstract}
Introduction. Modern nurses and midwives constantly update their knowledge and improve skills. The necessity of continuous professional development stems from the obligation imposed by the Act about the profession of nurses and midwives, Code of professional ethics, but also from the need to keep up with the constantly changing medical sciences.

Aim. The aim of the study was to analyze specialization courses held by nurses and midwives in the region of Koszalin, conducted within the framework of postgraduate training and to demonstrate whether the profession of nurse or midwife, seniority, place of residence, education and the workplace affected the number of specialization courses completed.

Material and methods. The study group was constituted of 153 nurses and 17 midwives registered in the District Chamber of Nurses and Midwives in Koszalin, who participated in postgraduate training. For the research we a used diagnostic survey method with the questionnaire technique. The research tool was a self-designed questionnaire containing 27 questions. The anonymous survey was analyzed descriptively, graphically and statistically.

Results. As a result of the research the following was concluded: 1. Nearly all the respondents had completed specialization courses. It shows high awareness of improving qualifications necessary to perform specific professional activities. 2. Most often the respondents completed a specialization training course 'Performing and Interpretation of ECG', then 'Cardiopulmonary resuscitation' and 'Protective vaccination'. 3. Place of work significantly influenced the number of completed specialization courses by the nurses and midwives. Other analyzed variables: seniority, education, structure of the profession and place of residence had no such effects.
\end{abstract}

KEYWORDS: postgraduate training, nurses, midwives.

mych chęci nadążania za zmianami, ale jest ściśle określona przepisami branżowymi, mówiącymi o obowiązku stałego aktualizowania swojej wiedzy i umiejętności zawodowych oraz prawie do doskonalenia zawodowe- 
go w różnych rodzajach kształcenia podyplomowego. Powinność systematycznego podnoszenia kwalifikacji zawodowych, „wdrażanie do praktyki nowych zdobyczy nauk medycznych, społecznych i humanistycznych" oraz „sprawowanie profesjonalnej opieki nad życiem i zdrowiem ludzkim" stają się bezwzględną powinnością każdej pielęgniarki i położnej zawartą w preambule Kodeksu etyki zawodowej pielęgniarki i położnej Rzeczypospolitej Polskiej [1, 2].

\section{Cel pracy}

Cele pracy to analiza ukończenia przez pielęgniarki i położne kursów specjalistycznych przeprowadzonych w ramach szkolenia podyplomowego oraz wykazanie, czy wykonywany zawód pielęgniarki lub położnej, staż pracy, miejsce zamieszkania, wykształcenie i miejsce pracy miały wpływ na liczbę ukończonych kursów specjalistycznych.

\section{Materiał i metody}

Badania przeprowadzono w okresie od października 2014 do marca 2015 r. W rejonie działania Okręgowej Izby Pielęgniarek i Położnych w Koszalinie zatrudnionych jest 2698 pielęgniarek i pielęgniarzy oraz 246 położnych. Grupę badaną stanowiły 153 (5,67\%) osoby z personelu pielęgniarskiego i 17 (6,91\%) położnych zarejestrowanych w koszalińskiej Izbie, które uczestniczyły w kształceniu podyplomowym. W celu przeprowadzenia badań zastosowano metodę sondażu diagnostycznego, wykorzystując technikę ankietową. Jako narzędzie badawcze posłużył samodzielnie skonstruowany kwestionariusz ankiety zawierającej 27 pytań. Anonimowe badania poddano analizie opisowej, graficznej oraz statystycznej. Do zbadania zależności statystycznej pomiędzy analizowanymi cechami użyto testu chi-kwadrat. Uzyskane wyniki badań poddano analizie statystycznej testem jednorodności $x^{2}$. Przyjęto $5 \%$ ryzyka błędu wnioskowania oraz ustalono wartości prawdopodobieństwa w następujących przedziałach:

- $\quad$ dla $p \geqslant 0,1$ - nie ma istotnego związku między zmiennymi,

- $\quad$ dla p w przedziale $<0,1 ; 0,05 \geqslant-$ związek między zmiennymi kształtuje się na granicy istotności statystycznej,

- dla $p<0,05$ - istnieje istotna statystycznie zależność między zmiennymi.

\section{Wyniki}

Wśród ankietowanych najliczniejszą grupę stanowiły osoby w wieku 41-50 lat (48,0\%). Drugą grupę pod względem liczebności tworzyli badani w przedziale wiekowym 51-60 lat, co stanowi 32,0\% respondentów. Wśród badanych najmniej liczną grupę stanowiły osoby w wieku powyżej 60 lat (2,0\%).
W strukturze zawodowej ankietowanych absolwentów kursów specjalistycznych zdecydowaną większość stanowiły pielęgniarki. W badaniu uczestniczyli 152 pielęgniarki i 1 pielęgniarz, co stanowiło 90,0\% badanej grupy. Ponadto w badaniu wzięło udział 17 położnych, stanowiąc $10 \%$ respondentów.

Zdecydowana większość to osoby o stażu pracy w przedziale 21-30 lat (49,0\%). Z drugiej strony najmniej liczną grupę reprezentowali respondenci posiadający staż pracy pomiędzy rokiem a 5 latami oraz do roku (odpowiednio 4,0\% i 5,0\% badanych).

Spośród badanej grupy największa liczba ankietowych zamieszkiwała w mieście do 50 tysięcy mieszkańców - było to $46,0 \%$ badanych. Drugą grupę pod względem liczebności stanowiły osoby zamieszkujące miasto powyżej 100 tysięcy mieszkańców (25,0\%). Niewiele mniej osób wskazało jako miejsce zamieszkania tereny wiejskie - wioski zarówno gminne, jak i sołeckie (23,5\%).

Analizując wykształcenie badanej grupy, zauważyć można, że większość wskazała na posiadanie wykształcenia średniego. Grupa ta stanowiła 59,0\% badanych, z kolei jedynie 9,0\% respondentów deklarowało posiadanie wykształcenia wyższego II stopnia (magister położnictwa bądź pielęgniarstwa).

Wśród ankietowanych większość zatrudniona była w szpitalach, z czego w publicznych $58,0 \%$, a $12,0 \%$ w niepublicznych. Tylko 5,0\% badanych pracowało w publicznym POZ, a 6,0\% - w niepublicznym. Dodatkowo wśród badanych 14,0\% stanowili zatrudnieni w sanatoriach. Na brak zatrudnienia wskazała 1 z położnych.

Tabela 1. Charakterystyka badanej grupy Table 1. Characteristics of the study group

\begin{tabular}{ccc}
\hline Wiek respondentów/Age & $\mathrm{N}=170$ & $\%$ \\
$20-30$ & 9 & 5,0 \\
$31-40$ & 24 & 14,0 \\
$41-50$ & 81 & 48,0 \\
$51-60$ & 53 & 31,0 \\
powyżej 60 lat/above 60 years & 3 & 2,0 \\
Struktura zawodu/The structure of the profession & $\mathrm{N}=170$ & $\%$ \\
położne/midwifes & 17 & 10,0 \\
pielęgniarki//nurses & 153 & 90,0 \\
Staż pracy/Seniority & $\mathrm{N}=170$ & $\%$ \\
do 1 roku/up till 1 year & 8 & 5,0 \\
1-5 lat/1-5 years & 7 & 4,0 \\
6-10 lat/6-10 years & 22 & 13,0 \\
11-20 lat/11-20 years & 31 & 18,0 \\
21-30 lat/21-30 years & 81 & 48,0 \\
powyżej 30 lat/above 30 years & 21 & 12,0 \\
Miejsce zamieszkania/Place of residence & $\mathrm{N}=170$ & $\%$ \\
wiés/commune & 35 & 21,0 \\
miasto do 50 tys. mieszkańców/city to 50 000 residents & 82 & 49,0
\end{tabular}




\begin{tabular}{ccc}
$\begin{array}{c}\text { miasto 50-100 tys. mieszkańców/city 50 000-100 000 } \\
\text { residents }\end{array}$ & 9 & 5,0 \\
$\begin{array}{c}\text { miasto powyżej } 100 \text { tys. mieszkańców/city over } \\
100000 \text { residents }\end{array}$ & 40 & 24,0 \\
$\begin{array}{c}\text { Wykształcenie kierunkowe/Professional education } \\
\text { średnie/post secondary }\end{array}$ & $\mathrm{N}=170$ & $\%$ \\
wyższe I stopnia/higher professional & 100 & 59,0 \\
(midwifery, nursing) & 54 & 32,0 \\
wyższe Il stopnia/higher master-level & 16 & 9,0 \\
Miejsce pracy/Workplace & $\mathrm{N}=170$ & $\%$ \\
szpital publiczny/public hospital & 98 & 58,0 \\
szpital niepubliczny/private hospital & 21 & 12,0 \\
POZ publiczny/public Primary Health Care & 8 & 5,0 \\
POZ niepubliczny/non-public Primary Health Care & 10 & 6,0 \\
opieka długoterminowa/long-term care & 4 & 2,0 \\
hospicjum stacjonarne/stationary hospice & 4 & 2,0 \\
sanatorium/sanatorium & 24 & 14,0 \\
nie pracuje/she/he does not work & 1 & 0,6 \\
\hline
\end{tabular}

Źródło: opracowanie własne

Source: author's own analysis

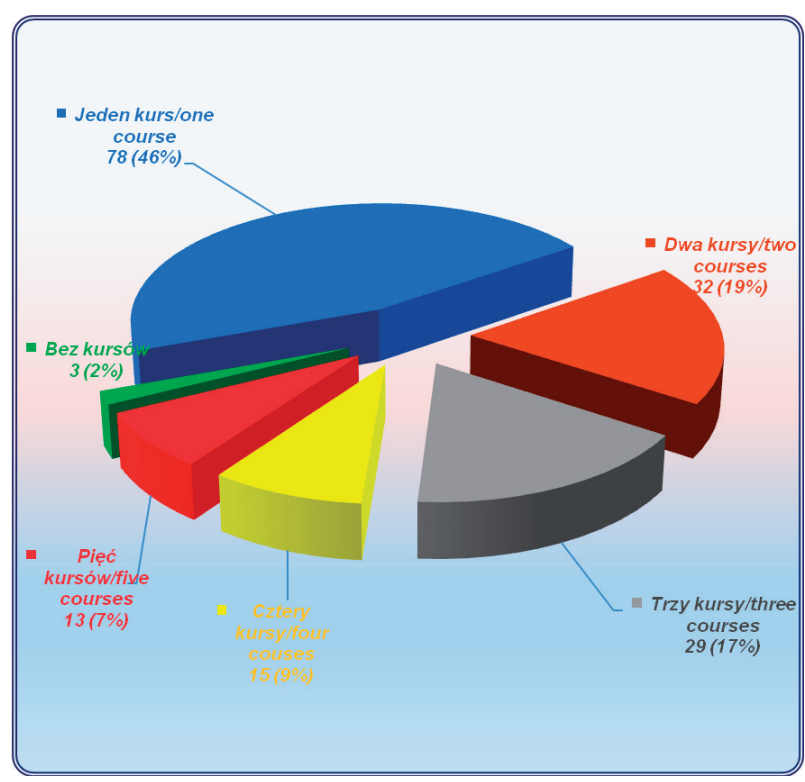

Rycina 1. Zestawienie ukończonych kursów specjalistycznych w badanej grupie

Figure 1. List of completed specialized courses in the study group

Źródło: opracowanie własne

Source: author's own analysis

Rycina 1 prezentuje deklarowaną liczbę ukończonych kursów przez ankietowanych. Spośród badanych 47,0\% wskazało, że odbyło 1 kurs. Kolejno 2 i 3 kursy - odpowiednio 19,0\% i 17,0\%. Ukończenie 4 kursów zadeklarowało 9,0\% badanych. Do grona osób, które nie ukończyły żadnych kursów specjalistycznych, należały 3 pielęgniarki mieszczące się w kolejnych przedziałach wiekowych od 31 do 60 lat.

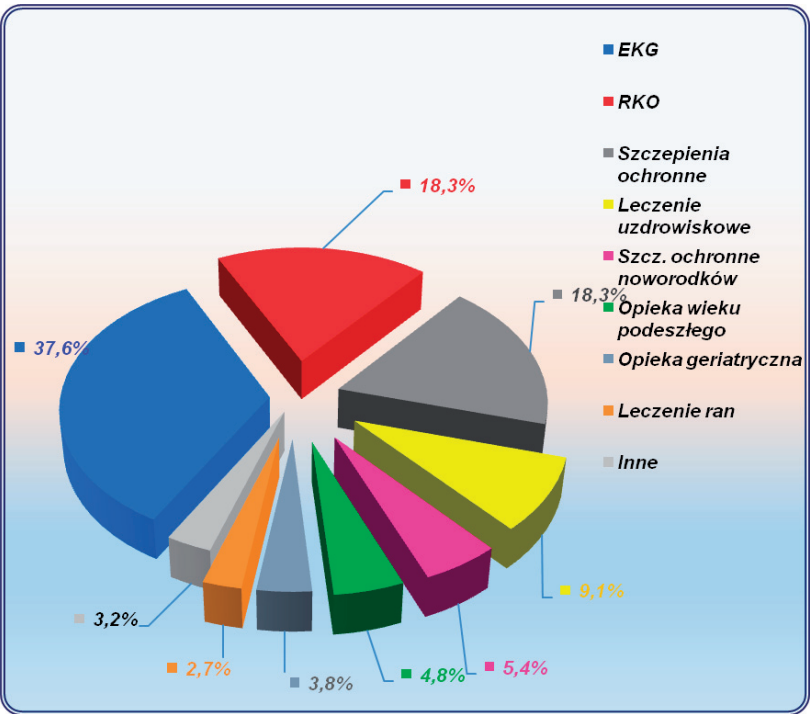

Szczepienia ochronne/Protective vaccination, Leczenie uzdrowiskowe/Spa treatment, Szczepienie ochronne noworodków/Protective vaccination of newborns, Opieka wieku podeszłego/Old age care, Opieka geriatryczna/Geriatric care, Leczenie ran/Treatment of wounds

Rycina 2. Zestawienie rodzajów kursów specjalistycznych ukończonych przez respondentów

Figure 2. List of types of specialized courses completed by respondents

Źródło: opracowanie własne

Source: author's own analysis

Spośród całego katalogu obejmującego 45 kursów specjalistycznych respondenci wymienili 13 dziedzin, w których ukończyli szkolenia kursowe. Wśród ukończonych kursów specjalistycznych najczęściej wskazywane było „Wykonanie i interpretacja zapisu elektrokardiograficznego (EKG)". Posiadanie takiego szkolenia deklarowało 64 ankietowanych, co stanowi 38,0\% wszystkich respondentów. Kolejnymi dziedzinami wskazywanymi przez badanych były: „Szczepienia ochronne” oraz „Resuscytacja krążeniowo-oddechowa (RKO)”. Oba kursy zostały wymienione równo przez 34 osoby, czyli po około jednej piątej uczestników badania. Zestawienie kursów przedstawiono na rycinie 2. W pozycji „Inne” ujęto kursy: „Endoskopia”, „Edukator w cukrzycy”, „Terapia bólu przewlekłego u dorosłych”, „Podstawy opieki paliatywnej”, „Wykonanie badania spirometrycznego”.

Tabela 2. Określenie stopnia zależności pomiędzy liczbą ukończonych kursów specjalistycznych a wykonywanym zawodem

Table 2. Determining the degree of relationship between the number of completed specialized courses and profession performed

\begin{tabular}{|c|c|c|c|c|c|c|}
\hline \multirow[b]{2}{*}{$\begin{array}{l}\text { Zawód/ } \\
\text { Profession }\end{array}$} & \multicolumn{6}{|c|}{ Liczba kursów/Number of courses } \\
\hline & $\begin{array}{c}5 \\
\text { kursów/ } \\
5 \\
\text { courses }\end{array}$ & $\begin{array}{c}4 \\
\text { kursy/ } \\
4 \\
\text { courses }\end{array}$ & $\begin{array}{c}3 \\
\text { kursy/ } \\
3 \\
\text { courses }\end{array}$ & $\begin{array}{c}2 \\
\text { kursy/ } \\
2 \\
\text { courses }\end{array}$ & $\begin{array}{c}1 \\
\text { kurs/ } \\
1 \\
\text { course }\end{array}$ & $\begin{array}{c}\text { Suma } \\
\text { końcowa/ } \\
\text { Total }\end{array}$ \\
\hline $\begin{array}{c}\text { Pielęgniarka/ } \\
\text { Nurse }\end{array}$ & $\begin{array}{c}13 \\
(7,78 \%)\end{array}$ & & $\begin{array}{c}28 \\
(16,77 \%)\end{array}$ & $\begin{array}{c}29 \\
(17,37 \%)\end{array}$ & $\begin{array}{c}66 \\
(39,52 \%)\end{array}$ & $\begin{array}{c}150 \\
(89,82 \%)\end{array}$ \\
\hline
\end{tabular}




\begin{tabular}{|c|c|c|c|c|c|c|}
\hline $\begin{array}{l}\text { Położna/ } \\
\text { Midwife }\end{array}$ & - & $\begin{array}{c}1 \\
(1,0 \%)\end{array}$ & $\begin{array}{c}1 \\
(1,0 \%)\end{array}$ & $\begin{array}{c}3 \\
(2,0 \%)\end{array}$ & $12(7,0 \%)$ & $17(10,0 \%)$ \\
\hline $\begin{array}{c}\text { Suma końcowa/ } \\
\text { Total }\end{array}$ & / $13(8,0 \%)$ & ) $15(9,0 \%)$ & $\begin{array}{c}29 \\
(17,0 \%)\end{array}$ & $\begin{array}{c}32 \\
(19,0 \%)\end{array}$ & $78(47,0 \%)$ & $\begin{array}{c}167 \\
(100,0 \%)\end{array}$ \\
\hline $\mathrm{Chi}^{\wedge} 2$ & 5,447 & & Interpre & tacja/Inte & erpretation & \\
\hline $\begin{array}{l}d f \\
p\end{array}$ & $\begin{array}{c}4 \\
0,244\end{array}$ & \multicolumn{5}{|c|}{$\begin{array}{l}\text { Nie ma istotnego związku mieedzy zmiennymi/ } \\
\text { There is not a statistically significant dependency } \\
\text { between the variables }\end{array}$} \\
\hline
\end{tabular}

Źródło: opracowanie własne

Source: author's own analysis

Zgodnie z przyjętymi wartościami dla poziomu istotności statystycznej $p \geqslant 0,1$ - otrzymany dla $p$ wynik 0,244 powoduje, iż hipotezę o tym, że wykonywanie zawodu pielęgniarki lub położnej ma statystyczne znaczenie co do liczby ukończonych kursów, należy odrzucić. Równocześnie należy stwierdzić, że pomiędzy wykonywanym zawodem a liczbą kursów, w jakich uczestniczyli badani, nie istnieje zależność statystyczna. Otrzymany wynik wskazuje, że w badanej grupie nie zachodzą żadne powiązania pomiędzy wykonywanym zawodem pielęgniarki lub położnej a liczbą ukończonych kursów specjalistycznych.

Tabela 3. Określenie stopnia zależności pomiędzy liczbą ukończonych kursów specjalistycznych a stażem pracy

Table 3. Determining the degree of relationship between the number of completed specialized courses and seniority

\begin{tabular}{|c|c|c|c|c|c|c|}
\hline \multirow[b]{2}{*}{$\begin{array}{l}\text { Staż pracy/ } \\
\text { Seniority }\end{array}$} & \multicolumn{6}{|c|}{ Liczba kursów/Number of courses } \\
\hline & $\begin{array}{c}5 \\
\text { kursów/ } \\
5 \\
\text { courses } \\
\end{array}$ & $\begin{array}{c}4 \\
\text { kursy/ } \\
4 \\
\text { courses }\end{array}$ & $\begin{array}{c}3 \\
\text { kursy/ } \\
3 \\
\text { courses }\end{array}$ & $\begin{array}{c}2 \\
\text { kursy/ } \\
2 \\
\text { s courses } \\
\end{array}$ & $\begin{array}{c}1 \\
\text { kurs/ } \\
1 \\
\text { course }\end{array}$ & $\begin{array}{c}\text { Suma } \\
\text { końcowa/ } \\
\text { Total }\end{array}$ \\
\hline $\begin{array}{l}\text { Do } 1 \text { roku/ } \\
\text { Up till } 1 \text { year }\end{array}$ & - & - & - & - & $\begin{array}{c}8 \\
(4,8 \%)\end{array}$ & $\begin{array}{c}8 \\
(4,8 \%)\end{array}$ \\
\hline $\begin{array}{l}1-5 \text { lat/ } \\
1-5 \text { years }\end{array}$ & - & - & $\begin{array}{c}3 \\
(1,8 \%)\end{array}$ & $\begin{array}{c}1 \\
(0,6 \%)\end{array}$ & $\begin{array}{c}3 \\
(1,8 \%)\end{array}$ & $\begin{array}{c}7 \\
(4,2 \%)\end{array}$ \\
\hline $\begin{array}{l}6-10 \text { lat/ } \\
6-10 \text { years }\end{array}$ & $\begin{array}{c}2 \\
(1,2 \%)\end{array}$ & $\begin{array}{c}2 \\
(1,2 \%)\end{array}$ & $\begin{array}{c}4 \\
(2,4 \%)\end{array}$ & $\begin{array}{c}7 \\
(4,2 \%)\end{array}$ & $\begin{array}{c}6 \\
(3,6 \%)\end{array}$ & $1(12,6 \%$ \\
\hline $\begin{array}{l}11-20 \text { lat/ } \\
11-20 \text { years }\end{array}$ & $\begin{array}{c}2 \\
(1,2 \%)\end{array}$ & $\begin{array}{c}4 \\
(2,4 \%)\end{array}$ & $\begin{array}{c}6 \\
(3,6 \%)\end{array}$ & $\begin{array}{c}4 \\
(2,4 \%)\end{array}$ & 9,0 & $1(18,6 \%)$ \\
\hline $\begin{array}{l}21-30 \text { lat/ } \\
21-30 \text { years }\end{array}$ & $\begin{array}{c}6 \\
(3,6 \%)\end{array}$ & $\begin{array}{c}8 \\
(4,8 \%)\end{array}$ & $\begin{array}{c}15 \\
(9,0 \%)\end{array}$ & & $\begin{array}{c}34 \\
(20,4 \%)\end{array}$ & $79(47,3 \%$ \\
\hline $\begin{array}{l}\text { Powyżej } 30 \text { lat/ } \\
\text { Above } 30 \text { years }\end{array}$ & $\begin{array}{c}3 \\
(1,8 \%)\end{array}$ & $\begin{array}{c}1 \\
(0,6 \%)\end{array}$ & $\begin{array}{c}1 \\
(0,6 \%)\end{array}$ & $\begin{array}{c}4 \\
(2,4 \%)\end{array}$ & $12(7,2 \%)$ & o) $21(12,6 \%$ \\
\hline $\begin{array}{c}\text { Suma końcowa } \\
\text { Total }\end{array}$ & $13(7,8 \%)$ & (J) & $\begin{array}{c}29 \\
(17,4 \%)\end{array}$ & $\begin{array}{c}32 \\
(19,2 \%)\end{array}$ & $\begin{array}{c}78 \\
(46,7 \%)\end{array}$ & $\begin{array}{c}167 \\
(100,0 \%)\end{array}$ \\
\hline $\mathrm{Chi}^{\wedge} 2$ & 22,640 & & Interpre & etacja/Inte & erpretatio & \\
\hline df & & $\begin{array}{l}\text { Nie ma i } \\
\text { There is }\end{array}$ & stotnegc & o związku & międz & zmiennymi/ \\
\hline$p$ & 0,693 & & & & & \\
\hline
\end{tabular}

Źródło: opracowanie własne

Source: author's own analysis
Otrzymane wyniki wskazują, że założenie zakładające wpływ posiadanego stażu pracy na liczbę ukończonych kursów specjalistycznych w badanej grupie jest nieprawdziwe. Oznacza to, że staż pracy nie miał wpływu na liczbę ukończonych kursów specjalistycznych oraz należy stwierdzić, że nie istnieje zależność pomiędzy stażem pracy ankietowanych a liczbą kursów specjalistycznych przez nich ukończonych. Większość badanych brała udział w 1 kursie i statystycznie nie jest istotne, jaki posiadali staż pracy.

Tabela 4. Określenie stopnia zależności pomiędzy liczbą ukończonych kursów specjalistycznych a miejscem zamieszkania

Table 4. Determining the degree of relationship between the number of completed specialized courses and place of residence

\begin{tabular}{|c|c|c|c|c|c|}
\hline \multirow[b]{2}{*}{$\begin{array}{l}\text { Miejsce zamieszkania/ } \\
\text { Place of residence }\end{array}$} & \multicolumn{5}{|c|}{ Liczba kursów/Number of courses } \\
\hline & $\begin{array}{cc}5 & 4 \\
\text { kursów/ } & \text { kursy/ } \\
5 & 4 \\
\text { courses } & \text { courses }\end{array}$ & $\begin{array}{c}3 \\
\text { kursyl } \\
3 \\
\text { courses }\end{array}$ & $\begin{array}{c}2 \\
\text { kursy/ } \\
2 \\
\text { courses }\end{array}$ & $\begin{array}{c}1 \\
\text { kurs/ } \\
1 \\
\text { course }\end{array}$ & $\begin{array}{l}\text { Suma } \\
\text { końcowal } \\
\text { Total }\end{array}$ \\
\hline Gmina/Commune & & $\begin{array}{c}1 \\
(0,6 \%)\end{array}$ & $\begin{array}{c}1 \\
(0,6 \%)\end{array}$ & $\begin{array}{c}2 \\
(1,2 \%)\end{array}$ & $\begin{array}{c}4 \\
(2,4 \%)\end{array}$ \\
\hline $\begin{array}{c}\text { Miasto } 50-100 \text { tys. } \\
\text { mieszkańców/City } \\
50 \text { 000-100 000 resi- } \\
\text { dents }\end{array}$ & $\begin{array}{cc}1 & 1 \\
(0,6 \%) & (0,6 \%)\end{array}$ & $\begin{array}{c}2 \\
(1,2 \%)\end{array}$ & $\begin{array}{c}2 \\
(1,2 \%)\end{array}$ & $\begin{array}{c}3 \\
(1,8 \%)\end{array}$ & $\begin{array}{c}9 \\
(5,4 \%)\end{array}$ \\
\hline $\begin{array}{l}\text { Miasto do } 50 \text { tys. } \\
\text { mieszkańców/City to } \\
50000 \text { residents }\end{array}$ & $\begin{array}{cc}9 & 7 \\
(5,4 \%) & (4,2 \%)\end{array}$ & $11(6,6 \%)$ & $\begin{array}{c}17 \\
(10,2 \%)\end{array}$ & $\begin{array}{c}35 \\
(21,0 \%)\end{array}$ & $\begin{array}{c}79 \\
(47,3 \%)\end{array}$ \\
\hline $\begin{array}{l}\text { Miasto powyżej } 100 \text { tys. } \\
\text { mieszkańców/City over } \\
100000 \text { residents }\end{array}$ & $\begin{array}{cc}2 & 5 \\
(1,2 \%) & (3,0 \%)\end{array}$ & $\begin{array}{c}6 \\
(3,6 \%)\end{array}$ & $\begin{array}{c}5 \\
(3,0 \%)\end{array}$ & $\begin{array}{c}22 \\
(13,2 \%)\end{array}$ & $\begin{array}{c}40 \\
(24,0 \%)\end{array}$ \\
\hline Wieś/Village & $\begin{array}{cc}1 & 2 \\
(0,6 \%) & (1,2 \%)\end{array}$ & $\begin{array}{c}9 \\
(5,4 \%)\end{array}$ & $\begin{array}{c}7 \\
(4,2 \%)\end{array}$ & $\begin{array}{c}16 \\
(9,6 \%)\end{array}$ & $\begin{array}{c}35 \\
(21,0 \%)\end{array}$ \\
\hline Suma końcowa/Total & $\begin{array}{c}13 \\
(7,8 \%)\end{array} \quad 15(9,0 \%)$ & b) $\begin{array}{c}29 \\
(17,4 \%)\end{array}$ & $\begin{array}{c}32 \\
(19,2 \%)\end{array}$ & $\begin{array}{c}78 \\
(46,7 \%)\end{array}$ & $\begin{array}{c}167 \\
(100,0 \%)\end{array}$ \\
\hline Chi^2 & 9,284 & Interpreta & acja/Inter & pretation & \\
\hline df & $\begin{array}{cr}16 & \begin{array}{r}\text { Związek } \\
\text { granicy } \\
\text { tionship }\end{array} \\
0,099 & \end{array}$ & $\begin{array}{l}\text { między zI } \\
\text { y istotnośc } \\
\text { o between } \\
\text { of statist }\end{array}$ & $\begin{array}{l}\text { miennymi } \\
\text { ci statysty } \\
\text { variables } \\
\text { tical signi }\end{array}$ & $\begin{array}{l}\text { i kształtc } \\
y c z n e j / T \\
\text { s is at the } \\
\text { ificance }\end{array}$ & $\begin{array}{l}\text { tuje się na } \\
\text { The rela- } \\
\text { he border }\end{array}$ \\
\hline
\end{tabular}

Źródło: opracowanie własne

Source: author's own analysis

Wyniki obliczeń wskazują, że związek między zmiennymi kształtuje się na granicy istotności statystycznej, przyjętej na poziomie $p \geqslant 0,1$. Oznacza to, że nie ma powodu do odrzucenia założenia, że miejsce zamieszkania ma wpływ na liczbę ukończonych kursów specjalistycznych. Jednocześnie należy stwierdzić, że obserwowany efekt jest dziełem przypadku. 
Tabela 5. Określenie stopnia zależności pomiędzy liczbą ukończonych kursów specjalistycznych a posiadanym wykształceniem

Table 5. Determining the degree of relationship between the number of completed specialized courses and education possessed

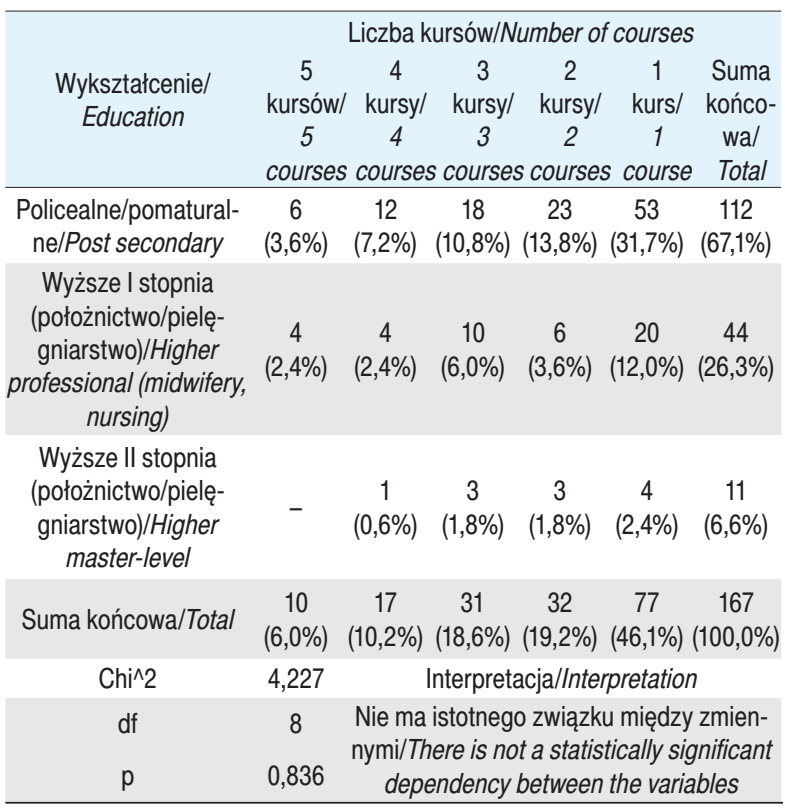

Źródło: opracowanie własne

Source: author's own analysis

Otrzymany wynik pozwala na stwierdzenie, że hipoteza o zależności statystycznej pomiędzy poziomem wykształcenia poszczególnych osób w badanej grupie a liczbą ukończonych kursów specjalistycznych jest nieprawdziwa, i że nie istnieje zależność pomiędzy wykształceniem ankietowanych a liczbą kursów, w jakich brali udział. Niezależnie od wykształcenia większość badanych wzięła udział w 1 kursie specjalistycznym.

Tabela 6. Określenie stopnia zależności pomiędzy liczbą ukończonych kursów specjalistycznych a miejscem pracy

Table 6. Determining the degree of relationship between the number of completed specialized courses and workplace

\begin{tabular}{|c|c|c|c|c|c|c|}
\hline \multirow[b]{2}{*}{$\begin{array}{l}\text { Miejsce pracy/ } \\
\text { Workplace }\end{array}$} & \multicolumn{6}{|c|}{ Liczba kursów/Number of courses } \\
\hline & $\begin{array}{c}5 \\
\text { kursów/ } \\
5 \\
\text { courses }\end{array}$ & $\begin{array}{c}4 \\
\text { kursy/ } \\
4\end{array}$ & $\begin{array}{c}3 \\
\text { kursy/ } \\
3\end{array}$ & $\begin{array}{c}2 \\
\text { kursy/ } \\
2 \\
2 \text { courses }\end{array}$ & $\begin{array}{c}1 \\
\text { kurs/ } \\
1 \\
\text { course }\end{array}$ & $\begin{array}{c}\text { Suma } \\
\text { końco- } \\
\text { wa/ }\end{array}$ \\
\hline $\begin{array}{l}\text { Szpital niepubliczny/ } \\
\text { Private hospital }\end{array}$ & $\begin{array}{c}4 \\
(2,4 \%)\end{array}$ & & $\begin{array}{c}3 \\
(1,8 \%)\end{array}$ & $\begin{array}{c}6 \\
(3,6 \%)\end{array}$ & $\begin{array}{c}9 \\
(5,4 \%)\end{array}$ & $\begin{array}{c}22 \\
(13,2 \%)\end{array}$ \\
\hline $\begin{array}{c}\text { Szpital publiczny/Pu- } \\
\text { blic hospital }\end{array}$ & $\begin{array}{c}8 \\
(4,8 \%)\end{array}$ & $\begin{array}{c}7 \\
(4,2 \%)\end{array}$ & $\begin{array}{c}22 \\
(13,2 \%)\end{array}$ & $\begin{array}{c}15 \\
(9,0 \%)\end{array}$ & $\begin{array}{c}46 \\
(27,6 \%)\end{array}$ & $\begin{array}{c}98 \\
(58,8 \%)\end{array}$ \\
\hline Pozostałe & $\begin{array}{c}1 \\
(0,6 \%)\end{array}$ & $\begin{array}{c}8 \\
(4,8 \%)\end{array}$ & $\begin{array}{c}4 \\
(2,4 \%)\end{array}$ & $\begin{array}{c}11 \\
(6,6 \%)\end{array}$ & $\begin{array}{c}23 \\
(13,8 \%)\end{array}$ & $\begin{array}{c}47 \\
(28,1 \%)\end{array}$ \\
\hline Suma ko & $\begin{array}{c}13 \\
(7,8 \%)\end{array}$ & $\begin{array}{c}15 \\
(9,0 \%)\end{array}$ & $\begin{array}{c}29 \\
(17,4 \%)\end{array}$ & $\begin{array}{c}32 \\
(19,2 \%)\end{array}$ & $\begin{array}{c}78 \\
46,7 \%)\end{array}$ & $\begin{array}{c}167 \\
(100,0 \%)\end{array}$ \\
\hline Chi^2 & 11,032 & & Interpreta & cja/Inter & oretation & \\
\hline $\mathrm{p}$ & 0,026 & $\begin{array}{r}\text { Istnieje } \\
\text { dzy zm } \\
\text { cant }\end{array}$ & $\begin{array}{l}\text { otna s } \\
\text { nymi//T } \\
\text { ender }\end{array}$ & $\begin{array}{l}\text { styczn } \\
\text { re is a s } \\
\text { betwe }\end{array}$ & $\begin{array}{l}\text { e zależn } \\
\text { tatistical } \\
\text { en the va }\end{array}$ & $\begin{array}{l}\text { ość mię- } \\
\text { lly signifi- } \\
\text { rriables }\end{array}$ \\
\hline
\end{tabular}

Źródło: opracowanie własne

Source: author's own analysis
Otrzymane wyniki pozwalają na przyjęcie za prawdziwą hipotezę, że zmienne statystyczne są zależne i występuje zależność statystyczna pomiędzy miejscem pracy a liczbą ukończonych kursów specjalistycznych. Badanie to wykazuje, iż ankietowani zatrudnieni w szpitalach brali udział w większej liczbie kursów niż osoby zatrudnione w innych placówkach.

\section{Dyskusja}

W Polsce kształcenie podyplomowe pielęgniarek i położnych zaczęło się rozwijać w latach 60. ubiegłego wieku dzięki staraniom Racheli Hunter, uznawanej za prekursorkę oraz orędowniczkę rozwoju kształcenia podyplomowego [3]. Kształcenie podyplomowe pielęgniarek i położnych, w tym również kursy specjalistyczne, na stałe wpisało się w kanony profesji pielęgniarstwa i położnictwa. Idea ich istnienia jest jednak rozumiana i definiowana w różny sposób. Badania przeprowadzone przez Cisoń-Apanasewicz i wsp. [4] wykazały, że zdecydowana większość pielęgniarek uważa kształcenie podyplomowe za istotny element doskonalenia zawodowego. Potwierdzają to badania własne, które wykazały, że tylko 2,0\% badanych nie ukończyło kursów specjalistycznych. Tak wysoki odsetek respondentów rozszerzających swoje kwalifikacje świadczy o tym, że zarówno pielęgniarki, jak i położne są świadome dokonanych wyborów zawodowych i wynikających z nich powinności związanych z doskonaleniem zawodowym. Mówią o tym również Nowakowska i Grabowska, podkreślając, jak istotne znaczenie w pielęgnacji podopiecznych ma zastosowanie nowoczesnego sprzętu specjalistycznego czy wdrażanie nowych procedur [3]. Do podobnych wniosków doszli Leńczuk-Gruba i wsp., twierdząc, że pielęgniarki i położne mają świadomość istnienia wielu różnych poziomów zadań zawodowych, dostrzegają potrzebę kształcenia podyplomowego oraz użyteczność wiedzy i umiejętności w wykonywaniu świadczeń pielęgniarskich i położniczych na wysokim, profesjonalnym poziomie [5].

Kursy specjalistyczne cieszą się popularnością ze względu na krótki czas ich trwania, stosunkowo niski koszt uczestnictwa oraz uzyskanie kwalifikacji niezbędnych do wykonywania określonych czynności zawodowych przy realizacji świadczeń pielęgnacyjnych, leczniczych i rehabilitacyjnych. Pielęgniarki i położne wybierają z całego katalogu obejmującego 45 kursów specjalistycznych te, które wzbogacają ich wiedzę i pozwalają uzyskać kwalifikacje wykorzystywane na określonych stanowiskach. Wśród ukończonych kursów specjalistycznych w badaniach własnych najczęściej wymieniano: „Wykonanie i interpretacja zapisu elektrokardiograficznego” (37,0\%), „Resuscytacja krążeniowo-oddechowa”, „Szczepienia ochronne” 
(po 18,0\%). Zbliżone wyniki uzyskała w swoich badaniach Krupińska - „Wykonanie i interpretacja zapisu elektrokardiograficznego” ukończyło 38,0\%, „Resuscytację krążeniowo-oddechową” - 24,0\%, „Szczepienia ochronne" - 23,0\% [6]. Z kolei w badaniach Ozgi i wsp. pielęgniarki uczestniczące w szkoleniu podyplomowym w medycynie ratunkowej na pierwszym miejscu wymieniały kurs specjalistyczny z resuscytacji krążeniowo-oddechowej (56,0\%), po ukończeniu którego mają możliwość znalezienia zatrudnienia w strukturach Zintegrowanego Ratownictwa Medycznego [7].

Nie wykazano, że struktura zawodu, staż pracy i wykształcenie mają istotny wpływ na liczbę ukończonych kursów specjalistycznych przez pielęgniarki i położne. Jeśli chodzi o miejsce zamieszkania, wykazano jego związek z liczbą kursów, ale kształtuje się on na granicy istotności statystycznej i należy stwierdzić, że obserwowany efekt jest dziełem przypadku. Jedynie miejsce pracy statystycznie istotnie wpłynęło na liczbę ukończonych kursów specjalistycznych. Pracujące w szpitalach publicznych pielęgniarki i położne znamiennie częściej ukończyły większą liczbę kursów niż pracownicy szpitali niepublicznych i pozostałych analizowanych jednostek.

\section{Wnioski}

1. Niemal wszyscy badani ukończyli kursy specjalistyczne. Świadczy to o wysokiej świadomości podnoszenia kwalifikacji niezbędnych do wykonywania określonych czynności zawodowych.

2. Najczęściej respondenci kończyli kurs specjalistyczny „Wykonanie i interpretacja zapisu elektrokardiograficznego”, następnie „Resuscytacja krążeniowo-oddechowa” i „Szczepienia ochronne".

3. Miejsce pracy statystycznie istotnie wpłynęło na liczbę ukończonych kursów specjalistycznych przez pielęgniarki i położne. Pozostałe analizowane zmiennie: staż pracy, wykształcenie, struktura zawodu i miejsce zamieszkania nie miały takiego wpływu.

\section{Piśmiennictwo}

1. Załącznik Nr 1 do Uchwały nr 9 IV Krajowego Zjazdu Pielęgniarek i Położnych z dnia 9 grudnia 2003 r. w sprawie uchwalenia „Kodeksu etyki zawodowej dla pielęgniarki i położnej Rzeczypospolitej Polskiej", http://www.nipip. pl/index. php/uchwaly/krajowych-zjazdow/iv-krajowegozjazdupielegniarek-i-poloznych/uchwaly/896-9-04-2003 (data dostępu: 18.04.2015).

2. Uchwała nr 9 IV Krajowego Zjazdu Pielęgniarek i Położnych z dnia 9 grudnia 2003 r. w sprawie uchwalenia „Kodeksu etyki zawodowej dla pielęgniarki i położnej Rzeczypospolitej Polskiej".

3. Nowakowska H, Grabowska H. Kształcenie podyplomowe pielęgniarek i położnych na terenie województwa pomorskiego w latach 1980-2000. Probl Piel. 2013; 21(4): 528-533.

4. Cisoń-Apanasewicz U, Gaweł G, Ogonowska D, Potok H. Opinie pielęgniarek na temat kształcenia podyplomowego. Probl Piel. 2009; 17(1): 32-37.

5. Leńczuk-Gruba A, Kobos E, Wójcik G. Motywy uczestnictwa pielęgniarek w kształceniu podyplomowym organizowanym przez Warszawski Uniwersytet Medyczny. Med Dydak Wych. 2009: 41(4): 23-26.

6. Krupińska E. Kształcenie podyplomowe pielęgniarek - potrzeba czy obowiązek. Piel Zdr Publ. 2011; 1, 4: 321-326.

7. Ozga D, Binkowska-Bury M, Marć M. Zainteresowanie pielęgniarek szkoleniem podyplomowym w medycynie ratunkowej. Prz Med Uniw Rzesz. 2006; 4: 275- 278.

Artykuł przyjęty do redakcji: 16.02.2016

Artykuł przyjęty do publikacji: 20.07.2016

Źródło finansowania: Praca nie jest finansowana z żadnego źródła. Konflikt interesów: Autorzy deklarują brak konfliktu interesów.
Adres do korespondencji:
Dorota Ćwiek
ul. Żołnierska 48
71-210 Szczecin
tel.: 914800 977, fax: 914800978
e-mail: dorota.cwiek@pum.edu.pl
Samodzielna Pracownia Umiejętności Położniczych
Pomorski Uniwersytet Medyczny w Szczecinie 